\title{
REVIEW
}

\section{Best practices to mitigate seabird bycatch in longline, trawl and gillnet fisheries - efficiency and practical applicability}

\author{
Svein Løkkeborg \\ Fish Capture Division, Institute of Marine Research, 5817 Bergen, Norway
}

\begin{abstract}
Growing concerns have been raised about incidental capture of seabirds in various fisheries. Here, studies testing measures to prevent seabird bycatch in longline, trawl and gillnet fisheries are reviewed in order to identify the most efficient mitigation methods. There is potential for considerable reduction in mortality rates in most longline fisheries because effective measures have been developed. However, there is no single solution as the efficiency of a measure is specific to each fishery. In demersal longline fisheries where northern fulmar is the dominant seabird captured, streamer lines have been proven to virtually eliminate mortality. In the fishery for Patagonian toothfish where interactions with albatrosses occur, night setting has resulted in considerable bycatch reductions. Night setting has also been proven to be efficient in pelagic fisheries, but this measure should be used in combination with streamer lines and weighted longlines in areas inhabited by nocturnal and diving birds. The main cause of mortality in trawl fisheries is collision with warp and netsonde cables, but studies are fragmentary. Interactions between cables and seabirds have been shown to be rare at times of no offal discharge, suggesting that a no-discharge policy would virtually eliminate mortality. Streamer lines have been proven to effectively reduce cable strikes under offal discharge. Measures to prevent birds from diving into the trawl net meshes have not been tested. Efficient mitigation methods that maintain target fish catch still have to be identified for gillnet fisheries. Future research in longline fisheries should fine-tune the most promising measures for each specific fishery. Effective measures identified for trawl fisheries need to be expanded to and tested in other areas where seabird interactions occur.
\end{abstract}

KEY WORDS: Seabird mortality $\cdot$ Fisheries $\cdot$ Bycatch $\cdot$ Mitigation measures $\cdot$ Efficiency

\section{INTRODUCTION}

The general impacts of fishing activities on the marine ecosystem are gradually receiving more attention (Gislason 1994). In addition to removing large biomasses of exploited marine species, fishing causes mortality of non-target species of benthos, fish, seabirds, sea turtles and marine mammals. Growing concerns have been raised about the numbers of seabirds that are incidentally killed in various types of fishing activities. Most attention has been given to bycatch of albatrosses in the longline fisheries of the Southern Ocean (Brothers 1991, Cherel et al. 1996, Weimerskirch et al. 1997). Field and modelling studies have shown that many southern albatross populations are in decline, and longline-induced mortality is regarded as an important factor contributing to this decline (Weimerskirch \& Jouventin 1987, Croxall et al. 1990, Moloney et al. 1994, Prince et al. 1994, Poncet et al. 2006) . 
Although reports on incidental capture of albatrosses, large petrels and other seabird species in various fisheries are numerous (e.g. Bartle 1991, Brothers 1991, Gales et al. 1998, Løkkeborg 1998, Brothers et al. 1999a, Gilman et al. 2003, Sullivan et al. 2006a), and this mortality constitutes a severe threat to many seabird populations, it is difficult to attribute population declines to a specific factor. The marine environment is subject to much natural variation, and this provides a noisy background for observing changes that can be directly attributed to fishing activities (Gislason 1994). Fisheries bycatch is only one of several humanmediated disturbances, and it is difficult to separate the effects of fishing from changes due to natural fluctuations and other anthropogenic events (Lewison et al. 2005). Furthermore, accurate information on the numbers of birds killed is difficult to obtain (Prince et al. 1998, Wienecke \& Robertson 2002), and estimates of annual fishing-induced mortality are poor because bird captures are rare and observations are generally few. As an example, Brothers (1991) estimated that 44000 albatrosses were killed annually in the Southern Ocean by the Japanese tuna longline fishery alone and this estimate has been widely cited (e.g. Moloney et al. 1994, Cherel et al. 1996, Weimerskirch et al. 1997, Bull 2007) although it is an extrapolation based on only 45 birds observed to have been caught. Bugoni et al. (2008) discussed the problems associated with estimating overall capture rates for a fleet or an ocean region, and stated that captures based on limited sampling (i.e. a small number of hooks or short time periods) tend to overestimate capture rates. However, there has been a general improvement in recent estimates due to large and representative datasets, dedicated seabird observers and robust statistical tools (Bugoni et al. 2008, Jiménez et al. 2010).

However, irrespective of the actual number of seabirds caught in a fishery and the consequent population level effects, it is not consistent with the principles of ecologically sustainable management for fisheries to take large numbers of non-target organisms such as seabirds (Løkkeborg \& Robertson 2002). The FAO Code of Conduct for Responsible Fisheries promotes the maintenance and conservation of biodiversity by minimizing fisheries impacts on non-target species. Fortunately, several mitigation measures capable of reducing the likelihood of seabird bycatch have been described (Brothers et al. 1999a, Sullivan et al. 2006b). As well as being efficient in minimizing bird capture, mitigation measures should be practical and easy to implement in commercial fishing, cause no loss of target catch, be enforceable, and provide fishermen with incentives to employ them (Gilman et al. 2003, 2005). In longlining, incidental seabird bycatch is a 2-fold problem as it also reduces gear efficiency and prof- itability due to the associated loss of baits to seabirds. Reduced seabird interactions in longline fisheries should increase bait retention and thus provide the incentive of achieving higher target catch rates.

Several studies have been carried out to test and improve different types of seabird avoidance methods. This article provides a short description of management and technical seabird mitigation measures that have been tested in longline, trawl and gillnet fisheries, and critically reviews their fishery suitability in terms of practical applicability and efficiency in mitigating incidental catch of seabirds. The focus is on longline fisheries where most of the work has been done, but trawl and gillnet fisheries are also included because these fishing practices cause significant mortality in some regions and promising mitigation measures have been developed and tested (Melvin et al. 1999, 2011, Sullivan et al. 2006a,b).

\section{CAUSES OF FISHING-INDUCED SEABIRD MORTALITY}

When longlines are set, the baited hooks float on the surface for a short while before they start sinking. During this period, baited hooks are available to foraging seabirds attracted to the fishing vessel. Seabirds are killed when they attack and seize floating hooks, become hooked in the bill or body and drawn underwater by the sinking longline. Diving seabirds may also seize baited hooks during the first part of the sinking phase, e.g. some small albatrosses may dive a few meters and species with deep diving abilities (Procellaria petrels and several shearwaters) may seize baited hooks much deeper. Occasionally, seabirds may become hooked when longlines are hauled (Brothers et al. 1999b), but birds hooked during line hauling are less likely to sustain lethal injuries and may be released alive with careful handling.

In trawl fisheries, high levels of seabird mortality have been associated with collisions with warp and netsonde (third-wire) cables (Bartle 1991, Weimerskirch et al. 2000, Sullivan et al. 2006a). The netsonde cable is an electronic connection between the vessel and the net sounder monitoring system on the headline of the trawl. The use of this equipment is currently banned in several regions (e.g. New Zealand, CCAMLR), but not in some northern hemisphere fisheries (e.g. Bering Sea, Norwegian Sea) (see Melvin et al. 2011). Mortalities caused by cable strikes mainly result from birds being dragged underwater when their wings become entangled around the trawl cable, whereas aerial collisions with cables have little impact on birds (Watkins et al. 2008). A second cause of mortality is diving into the trawl and becoming entangled 
in the meshes when the birds try to seize fish. The species of birds predominantly killed due to cable strikes differ from those killed after becoming entangled in trawl nets (Gonzalez-Zevallos \& Yorio 2006, GonzalezZevallos et al. 2007, Watkins et al. 2008, Favero et al. 2010), with warp strikes usually impacting larger species and net entanglements impacting smaller species.

Seabird mortality in gillnet fisheries occurs when diving seabirds encounter gillnets and become entangled in the net. As seabirds may encounter gillnets while they are set and hauled, seabirds may also be caught in nets set deeper than their maximum diving depth. Seabird bycatch has been documented in coastal and high-seas fisheries, as well as in drift and demersal gillnets (Melvin et al. 1999, Trippel et al. 2003, Zydelis et al. 2009).

\section{DESCRIPTION OF MITIGATION MEASURES}

\section{Longline fisheries}

Mitigation measures for longline fishing can be classified into 4 main categories:

1. Avoiding fishing in areas and at times when seabird interactions are most likely and intense (area and seasonal closures, night setting).

2. Limiting bird access to baited hooks (underwater setting devices, weighted lines, thawed bait, line shooter, bait-casting machine, side setting).

3. Deterring birds from taking baited hooks (streamer (bird scaring) lines, acoustic and olfactory deterrents, water cannons).

4. Reducing the attractiveness or visibility of the baited hooks (dumping of offal, artificial baits, bluedyed bait).

A comprehensive review and description of mitigation measures that are in place, being tested or recommended for reducing incidental catch of seabirds in longline fishing is given by Brothers et al. (1999a). Below, only measures/devices that have been developed, tested and proven to have potential in reducing incidental capture are discussed.

Avoiding fishing in areas and at times when seabird interactions are most intense. As seabird mortality in longline fisheries is related to the feeding activity of the birds, mortality rates vary with area and season, and have been shown to be higher close to breeding colonies (Moreno et al. 1996, Nel et al. 2002) and during breeding seasons (Ashford \& Croxall 1998, Nel et al. 2002, Reid et al. 2004). Area and seasonal closures of fishing grounds in the vicinity of breeding colonies during the breeding season may therefore prevent fishing vessels from operating when seabird interactions are most intense. However, high capture rates have also been recorded in foraging areas in the south Atlantic during the non-breeding season (Jiménez et al. 2009, 2010, Petersen et al. 2009).

Night setting. Most seabirds are visual feeders and forage during daylight hours. Therefore, setting longlines at night could reduce the number of birds attacking baited hooks, as well as their ability to see and seize baits.

Streamer line (bird scaring line, tori line). This is a line attached to a high point at the stern and towed behind the vessel while longlines are set (see Fig. 1a; Løkkeborg 1998, Melvin et al. 2004). The terminal end of the line has a towed device (e.g. buoys) to create drag and streamers are attached to its aerial portion above the sinking longline. The movements of the streamers deter seabirds from attacking baited hooks.

Weighted lines. Longlines with added weights sink faster and thus reduce the time baited hooks remain close to the surface and are available for seabirds to seize (Robertson et al. 2003). Weights can be added to longlines either by attaching (i.e. tying) external weights to the mainline at intervals (e.g. 40 m); including strands of lead inside each of the strands of the mainline (integrated weight line); or using weighted swivels at the branchline (Robertson 2001, Dietrich et al. 2008, Melvin et al. 2010). The first 2 ways of adding weights are used in demersal longlining, whereas the latter method is applied in pelagic longlining.

Underwater setting device (funnel, chute, capsule). This is a stern-mounted tube through which the baited hooks are set (Løkkeborg 1998, Gilman et al. 2003). This device delivers baited hooks underwater, thereby reducing the time they remain close to the surface and are visible and within the reach of seabirds. Both the mainline and the branchline (snood) are set through the underwater setting funnel developed for demersal longlining, whereas in pelagic longlining, only the branchline and the baited hooks are fed through the device (named the 'chute'). A second emerging method for setting pelagic longlines is the underwater setting capsule. The baited hook is placed in a capsule that slides down a carriage way and releases the baited hook at a pre-determined depth. The capsule is then returned on board to be loaded with the next hook.

Line shooter. This device is designed to set longlines without tension. During traditional setting, lines are set with tension, which is believed to delay line sinking and keep baits available to birds longer compared to lines set with slack (Melvin et al. 2001, Løkkeborg \& Robertson 2002, Robertson et al. 2008). A line shooter consists of opposing rubber and metal sheaves or wheels through which the mainline is pulled in order to lay the line out at speeds faster than the vessel speed during line setting. Long branchlines are used in 
pelagic longlining, and the hooks are deployed slack independent on the shooter.

Bait-casting machine (bait thrower). This device is used only in pelagic longlining to prevent entangling of the long branchlines with the mainline (Klaer \& Polacheck 1998, Brothers et al. 1999b). Bait-casting machines throw baited hooks to the side far outside the propeller wash and hull turbulence. Throwing baits into the propeller wash may cause delayed line sinking.

Side setting. Side setting, as opposed to traditional stern setting, reduces the time baited hooks remain within the reach of seabirds. Lines set at the side of the vessel enter the water several meters in front of the stern, and thus commence sinking sooner and have sunk to a certain depth when they emerge clear of the stern (see Yokota \& Kiyota 2006, Gilman et al. 2007).

Strategic offal discharge. Dumping of homogenized offal to the side of the vessel during setting may attract birds to this area and away from the baited hooks (Cherel et al. 1996, Weimerskirch et al. 2000). This mitigation method is only applicable in fisheries where line setting is short and allows dumping throughout the setting operation.

Blue-dyed bait. Baits dyed blue, with blue ocean as the background, are less visible to seabirds (Boggs 2001, Cocking et al. 2008). These baits become invisible to seabirds at shallower depth and therefore sooner than baits with clearer contrast.

Olfactory deterrents. This involves the release of biogenic chemical deterrents (e.g. fish liver oil) on the sea surface behind the vessel while longlines are set (Pierre \& Norden 2006, Norden \& Pierre 2007). Olfactory deterrents may reduce the numbers of seabirds attending longline vessels and the number of attacks on baited hooks.

\section{Trawl fisheries}

The mitigation measures that have been developed and tested in trawl fisheries are all designed to reduce cable strikes. Although mitigation measures that prevent seabirds from diving into the trawl and becoming entangled in the meshes have been described, research has not been carried out to demonstrate their effectiveness (but see Roe 2005 cited by Bull 2009). This review has identified 6 measures, which are based on the principle of deterring birds from coming into contact with the warp or netsonde cables. Detailed descriptions and drawings of these mitigation devices are given in the original papers (Sullivan et al. 2006b, Gonzalez-Zevallos et al. 2007, Melvin et al. 2011).

Streamer line. This mitigation method is similar to the streamer lines used on longliners. To adapt these for use on trawlers and deter seabirds from collision with the warp and netsonde cables, streamer lines are suspended on each side of the vessel (Sullivan et al. 2006b).

Warp scarer. This device consists of a series of ring style devices with rollers installed, allowing the device to slide up and down the warp freely and stay aligned with each warp. The rings are joined by a length of netting and streamers hang from each ring to the sea surface (see Fig. 1 in Sullivan et al. 2006b). These devices create a protective area around the warp, deterring seabirds from colliding with the warp. The warp scarer is deployed after shooting the net and is retrieved prior to hauling.

Brady baffler. The baffler is designed to prevent seabirds scavenging for offal from congregating at the stern where the warp cables enter the water. It consists of 2 booms attached to each of the 2 stern quarters. Two of these booms extend out from the sides of the vessel and the other 2 extend backwards from the stern. Ropes with plastic cones at the seaward end are lowered from each boom to create a curtain to deter seabirds from the area adjacent to the warp (see Fig. 2 in Sullivan et al. 2006b).

Warp boom. This is similar to the Brady baffler, but has only one boom installed on the outboard face of the gantry (Melvin et al. 2011). Streamers are suspended along each boom such that the ends of the lines are dragged in the water.

Cone. This is a $1 \mathrm{~m}$ long plastic cone $(10$ and $20 \mathrm{~cm}$ minimum and maximum diameter) that can be opened in half and attached to each warp cable (GonzalezZevallos et al. 2007). The cone is attached to a rope and slid down the warp cable to the point where the cable enters the water. It deters seabirds from this area.

Third-wire snatch block. A snatch block pulls the third (netsonde) wire closer to the water surface at the stern to reduce its aerial extent (the length of the wire from the stern to the water interface) (Melvin et al. 2011).

\section{Gillnet fisheries}

Technical mitigation measures that have been tested in gillnet fisheries are few. This review identified only 3 measures that have been proposed and tested, of which two are based on alerting seabirds to the presence of gillnets and one is based on reducing encounters with gillnets by setting nets deeper than the diving depth of seabirds (Melvin et al. 1999, Trippel et al. 2003):

Visual alerts. Traditional gillnets are modified with visual alerts to increase their visibility, e.g. by dyeing the nets with an opaque colour (Melvin et al. 1999, 
Trippel et al. 2003). Seabirds should be able to detect these nets at greater distances and may thus avoid collision and entanglement. However, increased visibility of gillnets may also lead to reduced catches.

Acoustic alerts. Acoustic pingers that emit a sound signal within the hearing frequency of seabirds are attached to traditional gillnets (Melvin et al. 1999). The sound signal serves to scare off seabirds from gillnets.

Subsurface setting. Setting gillnets at greater depth could potentially reduce seabird interactions and bycatch (Hayase \& Yatsu 1993 cited by Melvin et al. 1999).

\section{METHODOLOGICAL CONSIDERATIONS}

The effectiveness of different mitigation measures in reducing incidental catches of seabirds was determined by using 2 approaches. One is based on observer data and relates seabird bycatch rates recorded by observers to their notes on factors such as type of mitigation measure used (e.g. streamer line), time of setting (day/night), lunar phase, season and area fished. The other approach applies an experimental design to compare seabird catch rates of longline sets using mitigation measures with those of sets with no mitigation device (control). Only the latter approach can provide reliable data for determining the effectiveness of a particular mitigation measure, although permits to fish without using mitigation measures may not be achievable in some locations with endangered species.

Seabird catch rates obtained from observer data are affected by several variables, and some variables and their effect may be influenced by or correlated with the presence of other variables. For example, analyses of observer data from Japanese tuna longline vessels operating in the Australian Fishing Zone (1991-1995) showed higher seabird catch likelihood when a bird scaring line was used than when none was used (Brothers et al. 1999b). This unexpected result was due to the fact that use of bird lines was more prevalent in areas and seasons with typically higher seabird catch rates, and they were not used at night when the catch rate is low. Thus, analyses of the effects of single variables may be problematic and even misleading, and any results of observer data analyses must be interpreted with caution.

Unfortunately, most studies in pelagic longline fisheries, and also several studies in demersal fisheries in the Southern Ocean, are based on observer data; there are few, if any, comprehensive studies in pelagic longline fisheries that use an experimental approach to compare the effectiveness of different mitigation measures. The problem with applying an experimental approach to test mitigation measures in pelagic longlining is that seabird capture in most of these fisheries is a rare event, which is also the case for several demersal fisheries, and large numbers of hooks have to be set in order to obtain conclusive results. Some studies therefore used the number of contacts between seabirds and baited hooks or the rate of bait loss, rather than the number of birds caught, as an alternative measure to evaluate the effectiveness of mitigation devices. Furthermore, an experimental approach should include a control treatment where lines are set without any mitigation device, which would increase the risk of catching endangered and threatened species such as albatrosses. There is no other way to determine the effectiveness of a mitigation measure; thus, studies using an experimental approach should be undertaken with the knowledge that the death of a few seabirds in such experiments may ultimately lead to measures that will save many more in the longer term.

\section{STUDIES ON MITIGATION MEASURES IN LONGLINE FISHERIES}

\section{Demersal longlining}

Table 1 gives an overview of mitigation studies conducted in demersal fisheries. The streamer line is the most widely tested mitigation measure in demersal longlining. Comprehensive studies testing the efficiency of this device have been conducted under commercial fishing conditions in Alaska and in the northeast Atlantic. The longline fisheries in these 2 regions are similar in terms of gear design, target species and seabirds caught (mostly northern fulmars Fulmarus glacialis and gulls). In Alaska, however, regulatory and conservation attention is focused on bycatch of the endangered short-tailed albatross Phoebastria albatrus, whereas the northern Atlantic is not inhabited by albatrosses.

Single and paired streamer lines, weighted lines, setting funnels and line shooters have been tested in the 2 major Alaskan demersal longline fisheries targeting sablefish Anoplopoma fimbria and Pacific cod Gadus macrocephalus, respectively (Melvin et al. 2001). A total of 1.2 and 6.5 million hooks were set, and 113 and 430 seabirds (primarily northern fulmars, but also short-tailed shearwaters Puffinus tenuirostris and Laysan albatross Phoebastria immutabilis) were caught in the sablefish and cod fisheries, respectively.

Paired streamer lines were proven to be the most efficient solution among the mitigation measures tested, reducing seabird bycatch by 88 to $100 \%$ relative to controls with no deterrent. Thus, paired streamer lines virtually eliminated the catch of surface 


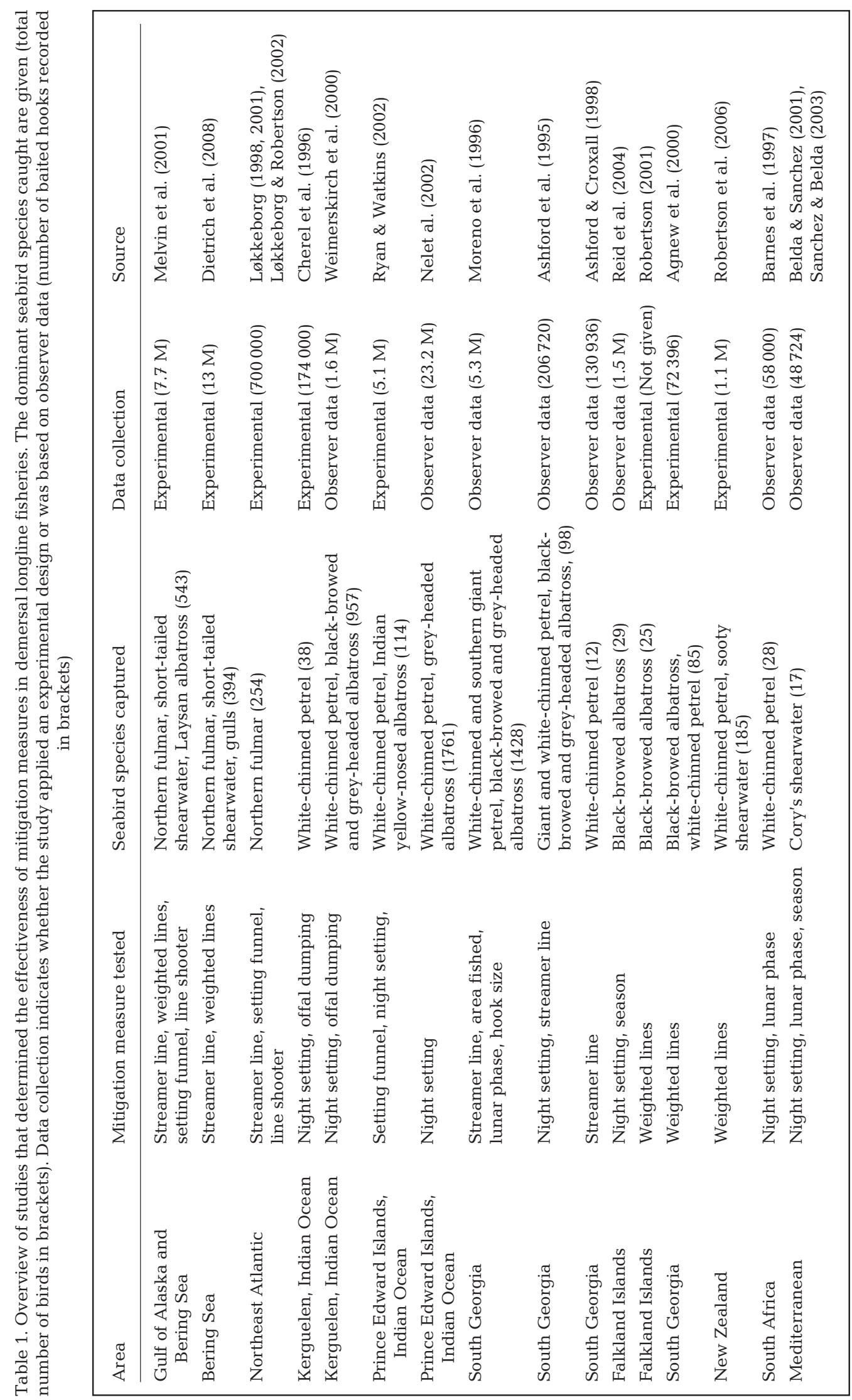


foraging seabirds. Single streamer lines were slightly, but not significantly less effective than paired streamer lines, and reduced seabird bycatch by 71 and $96 \%$ in the cod and sablefish fisheries, respectively. Adding weights to the longlines reduced seabird bycatch by $37 \%$ relative to the control in the sablefish fishery, and by $76 \%$ in the cod fishery. The setting funnel (tested only in the cod fishery) reduced seabird bycatch to a similar level $(79 \%)$ as that of line weighting, whereas the line shooter caused increased rates of seabird bycatch. Dietrich et al. (2008) tested paired streamer lines in combination with integrated weight longlines in the cod fishery. This mitigation treatment performed better than streamer lines or integrated weight lines alone, eliminating surface foraging seabird (fulmars and gulls) catch completely and reducing diving seabird (short-tailed shearwater) catch by $97 \%$, compared to the control of no deterrent.

Similar mitigation measures (streamer line, underwater setting funnel, and line shooter) have been tested in the northeast Atlantic on Norwegian commercial autoliners during 4 experimental cruises (Løkkeborg \& Bjordal 1992, Løkkeborg 1998, 2001, Løkkeborg \& Robertson 2002) and the results are summarized and reviewed by Løkkeborg (2003). Almost all seabirds caught were northern fulmars (in total, 700000 hooks were set and 254 seabirds were caught).

Also in these experiments, the streamer line was proven to be the most efficient device, and virtually eliminated seabird catches. Only 2 birds were caught when a total of 185000 hooks were set using the streamer line compared to 205 birds for controls with no mitigation device (99\% reduction). The 2 birds were hooked under conditions of strong side wind that brought the streamer line out of its ideal position right above the baited longline. The underwater setting funnel reduced seabird bycatch by 72 and $92 \%$ in the 2 cruises testing this device. Differences in pitch angle due to the loading of the vessel and thus differences in the submerged depth of the funnel are the most likely explanation for this difference in performance (Løkkeborg 2001). Seabird bycatch was reduced by $59 \%$ for longlines set with the line shooter compared to the control, although this reduction was not statistically significant (Løkkeborg \& Robertson 2002).

The Patagonian toothfish (Dissostichus eleginoides) fishery in the Southern Ocean is an important demersal longline fishery that draws serious conservation concern due to its interactions with albatrosses and petrels. Night setting is the most widely tested mitigation measure in this fishery, and several studies have demonstrated considerable reductions in mortality rates for longlines set at night, particularly for albatrosses (Ashford et al. 1995, Cherel et al. 1996,
Weimerskirch et al. 2000, Nel et al. 2002, Ryan \& Watkins 2002, Reid et al. 2004). Observer data from 4 longliners operating in Kerguelen waters during 4 successive fishing seasons showed that only one of a total of 78 albatrosses was caught on longlines set at night (Weimerskirch et al. 2000), and bycatches of whitechinned petrels (Procellaria aequinoctialis) were reduced by 60 to $80 \%$ (Cherel et al. 1996, Weimerskirch et al. 2000). Consequently, seabird mortality decreased considerably in this fishery after day setting was banned. Observer data from the toothfish fishery around the Prince Edward Islands demonstrated that albatrosses and giant petrels (Macronectes sp.) were caught almost exclusively during day sets (Nel et al. 2002). The only seabird species caught at night around South Georgia was white-chinned petrel (Ashford et al. 1995), and no birds were observed to have been caught on hooks set at night in waters of the Falkland Islands (Reid et al. 2004). Night setting has also been proven to be an efficient mitigation measure in other fisheries and regions such as the hake fisheries off South Africa (Barnes et al. 1997) and in the Mediterranean (Belda \& Sanchez 2001, Sanchez \& Belda 2003). It is important to note that night setting has been shown to be less efficient if the decklights are on or during the time of a full moon (Cherel et al. 1996, Moreno et al. 1996, Belda \& Sanchez 2001, Sanchez \& Belda 2003, Jiménez et al. 2009); however, bycatch of white-chinned petrels in the southwest Atlantic was not affected by the lunar cycle (Gómez-Laich \& Favero 2007).

Analyses of observer data based on 5.3 million hooks set and 1428 seabirds killed in the toothfish fishery around South Georgia showed that mortality rates were $<0.1$ birds per 1000 hooks for vessels using streamer lines compared to $>0.3$ birds for vessels without streamer lines (Moreno et al. 1996). Similar reductions in incidental mortality ( $3 \times$ lower) were obtained off Prince Edward Islands using the setting funnel (Ryan \& Watkins 2002). Season and area have also been shown to have considerable effects on seabird mortality in that bycatch rates were much higher for vessels operating during the breeding season and closer to breeding colonies (Moreno et al. 1996, Ashford \& Croxall 1998, Nel et al. 2002, Reid et al. 2004).

The effect of dumping offal during line setting was investigated in the toothfish fishery in Kerguelen waters (Cherel et al. 1996). Only one seabird was caught during 41 longline settings with concomitant release of homogenized offal compared to 33 birds (mainly white-chinned petrels) during 28 settings without the release of offal (98\% reduction). In a second study conducted in this fishery, dumping of offal during line setting reduced the mortality of whitechinned petrels by $54 \%$ (Weimerskirch et al. 2000). 
Pronounced increases in sink rates have been documented for longlines with both external and integrated weights (Robertson 2001, Robertson et al. 2003, 2007). In the toothfish fishery at South Georgia, weights of $8.5 \mathrm{~kg}$ attached at $40 \mathrm{~m}$ intervals gave an $80 \%$ reduction in bird mortality compared to weights of $4.25 \mathrm{~kg}$ (0.8 vs. 4.0 birds per 1000 hooks, respectively) (Agnew et al. 2000). A new gear design based on the traditional Spanish double line system has been developed in the Chilean toothfish fishery in order to eliminate depredation of fish by killer and sperm whales. The configuration of this system is such that all the baited hooks are directly above the weights ensuring a rapid sink rate (see Moreno et al. 2008). During the 2006 season when the Chilean industrial fleet of 11 vessels used this system, no seabirds were killed. This result was explained by the rapid sink of the new longline gear (Moreno et al. 2008). This new gear design has been used by vessels targeting toothfish in waters of the Falkland Islands since 2007, and seabird interactions were shown to have been reduced in comparison with the Spanish system (Brown et al. 2010).

White-chinned petrel and sooty shearwater Puffinus griseus are among the most difficult species to deter from baited hooks because of their deep diving abilities (13 and 67 m, respectively; Huin 1994, Weimerskirch \& Sagar 1996) and white-chinned petrel forage day and night (Weimerskirch et al. 2000). Lines with integrated weight $(50 \mathrm{~g}$ $\mathrm{m}^{-1}$ beaded lead core, sink rate: $0.24 \mathrm{~m} \mathrm{~s}^{-1}$ ) yielded a 94 to $99 \%$ reduction in the capture of white-chinned petrels and a $61 \%$ reduction for sooty shearwaters compared to unweighted conventional lines (sink rate: $0.11 \mathrm{~m} \mathrm{~s}^{-1}$ ) in the New Zealand ling (Genypterus blacodes) fishery (Robertson et al. 2006).

\section{Pelagic longlining}

Night setting has also been widely tested in the pelagic fisheries in the Southern Ocean (Table 2). Analyses of observer data from Japanese tuna longline vessels operating in the Australian Fishing Zone from 1991 to 1995 showed an $85 \%$ reduction in seabird bycatch for hooks set at night (Brothers et al.

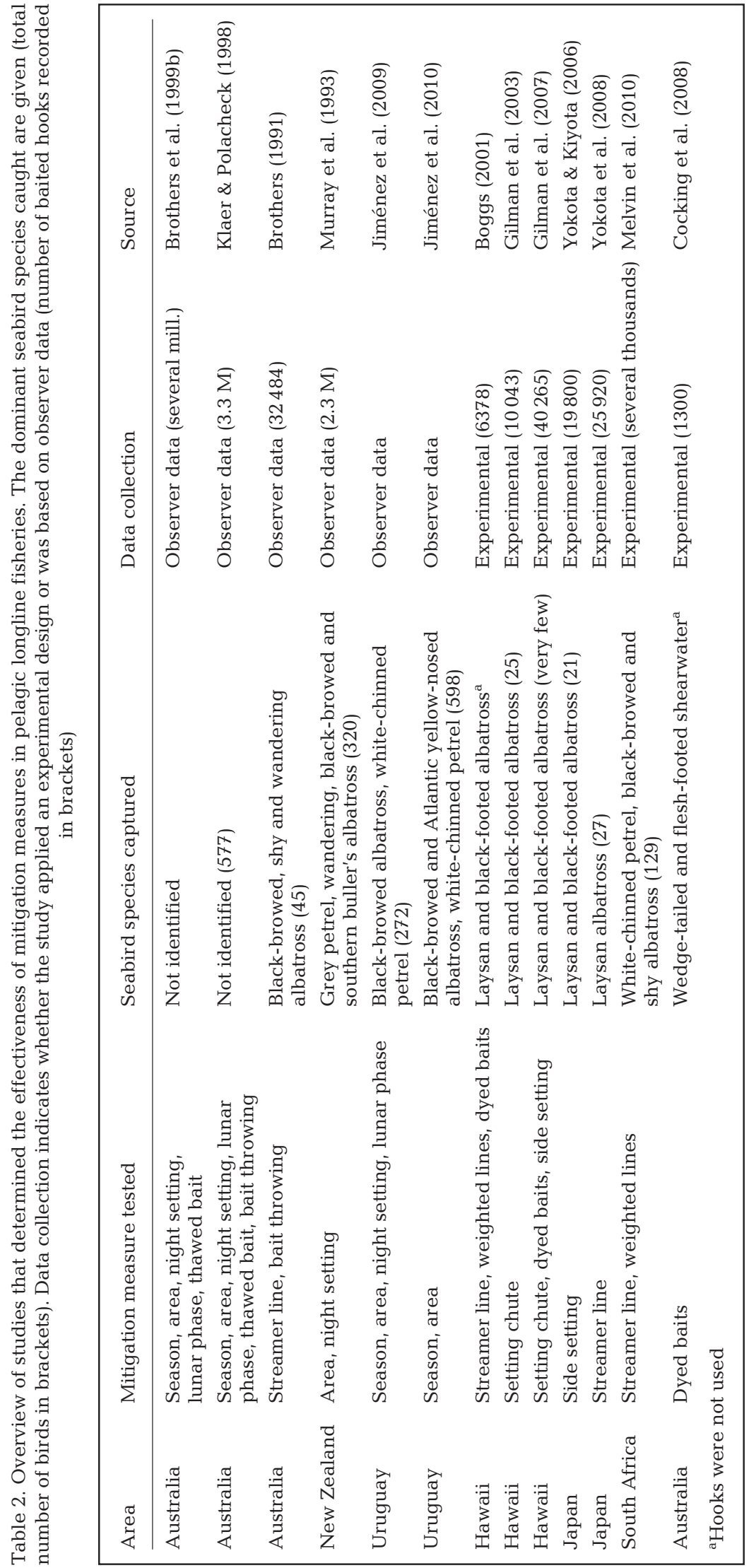


1999b). Moreover, seabirds were 3.6× more likely to be caught on night set hooks set in bright moonlit condition than on those set when there was no moon light. A subset of Australian observer data (1992 to 1995) was analysed in an effort to partly overcome the problems discussed above, e.g. excluding data from areas with very low seabird catch rates (Klaer \& Polacheck 1998). In this analysis, the seabird catch rates were $79 \%$ lower at night than during the day, and night sets during the new moon had $82 \%$ lower probability of catching seabirds compared to sets made during the full moon. Analyses of observer data from the Uruguayan pelagic fishery also showed higher mortality rates in night sets with full and first quarter moon compared to new and last quarter moon (Jiménez et al. 2009). Finescale analysis of observer data from New Zealand waters showed that night setting was a more efficient mitigation measure in areas dominated by albatrosses than in areas dominated by petrels (Murray et al. 1993).

Analyses of observer data from Japanese tuna vessels operating in Australian waters showed that bait loss to albatrosses was reduced by $69 \%$ when a streamer line was used (Brothers 1991). To prevent bird mortality, Boggs (2001) replaced hooks with net pins to hold the bait and showed that the streamer line reduced contacts between baits and albatrosses by $\sim 70 \%$ in a study carried out on board a research vessel mimicking the Hawaiian longline swordfish fishery. Assuming that albatross mortality is proportional to the number of times birds make contact with the bait, these studies demonstrated that the streamer line also has the potential of significantly reducing mortality in pelagic longline fisheries.

When using the underwater setting chute in the Hawaiian longline tuna fishery, no seabirds were caught, whereas 22 Laysan and 3 black-footed albatrosses were caught without the chute deployed (Gilman et al. 2003). Moreover, the chute was 98\% effective in reducing albatross contacts with baited hooks, and bait loss was reduced from 31 to $10 \%$ when the chute was used.

Observer data from Japanese tuna longline vessels showed that fishing season and fishing area strongly influenced seabird catch likelihood in Australian waters (Brothers et al. 1999b). For example, birds were $\sim 7 \times$ more likely to be caught during summer than during winter, and the catch likelihood for Tasmania was one order of magnitude higher than that for northeastern Australia. Analyses of a subset of these observer data confirmed that area and season have significant effects on seabird mortality (Klaer \& Polacheck 1998). Large spatio-temporal variations in the incidental capture of seabirds have also been shown for the Uruguayan pelagic longline fishery (Jiménez et al. 2009,
2010), and for the pelagic longline fishery off southern Africa (Petersen et al. 2009). Observer data from New Zealand showed that the vulnerability of species differed with fishing areas in that nearly all birds caught in the south were albatrosses, whereas most birds caught in the north were petrels (Murray et al. 1993).

An experiment was conducted to determine factors affecting the sink rates of baited hooks in the Australian pelagic longline fishery (Robertson et al. 2010a). Live mackerel bait sank much more slowly than dead bait. Increasing the weight of leaded swivels gave faster sink rates, but only for branchlines with short leader length (distance between leaded swivel and hooks). Thus, the fastest sink rates were associated with dead bait and heavy swivels placed close to hooks. In the South African tuna fishery, seabird catch rates were much lower on weighted $(60 \mathrm{~g}$ placed $70 \mathrm{~cm}$ from the hook) than on unweighted branchlines (Melvin et al. 2010). Baits with added weight reduced contacts between baits and albatrosses by $\sim 90 \%$ in an experiment on board a research vessel using the Hawaiian longline swordfish technique (Boggs 2001).

A mainline that was deployed loose with a shooter was shown to slow the sink rates of baited hooks compared to a mainline set without a line shooter, i.e. set tight with no slackness (Robertson et al. 2010b). The difference was explained by the fact that loose mainlines were set directly into the area affected by propeller turbulence, whereas tight mainlines entered the water aft of this area. However, the effect of propeller turbulence on the rate at which baited hooks sink is poorly understood as is the relationship between line tension and seabird mortality.

Thawed baits are believed to sink faster than frozen baits, and thawing the bait has been found to reduce seabird catch rate (Klaer \& Polacheck 1998, Brothers et al. 1999b). However, these studies were based on observer data and results of single variable analyses must be interpreted with caution (see above). Robertson (2010a) concluded that the bait thaw status has no practical bearing on seabird mortality in pelagic fisheries because the effect on sink rates is very minor. Studies on the effects of using bait throwers are also inadequate, and the results are conflicting (Klaer \& Polacheck 1998, Brothers et al. 1999b). For bait throwers to be effective, the baited hooks need to be landed under the streamer line; however, these studies lack information on how the measures were used.

A $68 \%$ reduction in interactions between seabirds (mainly shearwaters) and blue-dyed squid baits compared to non-dyed squid was observed in an Australian study (Cocking et al. 2008). Similar reduction was not found for blue-dyed fish baits. Squid baits dyed blue reduced contacts between baits and albatrosses by $\sim 90 \%$ in a Hawaiian research cruise (Boggs 2001). 
Studies testing the efficacy of fish liver oil in reducing interactions with seabirds have been carried out in New Zealand (Pierre \& Norden 2006, Norden \& Pierre 2007). Of 4 fish oils tested, shark liver oil was the most effective deterrent of interactions with fleshfooted shearwaters Puffinus carneipes, but it did not deter albatrosses or petrels.

\section{Evaluation of mitigation measures in longline fisheries}

Streamer line. The CCAMLR (Commission for the Conservation of Antarctic Marine Living Resources) is the first management body to implement a conservation measure that required all longline vessels fishing in its convention area to use a streamer line (Conservation Measure 29/X adopted by CCAMLR in 1991). Later, streamer lines were implemented in Alaskan waters (1997), and have become the most commonly applied seabird mitigation measure in longline fisheries throughout the world (Melvin et al. 2004). This review shows that all studies applying an experimental approach have documented that this measure is very efficient, particularly for demersal fisheries (Fig. 1a, Table 3).

Streamer lines are likely to be less efficient in reducing bycatch of diving seabirds, particularly in pelagic fisheries, as birds may still reach baited hooks beyond their aerial extent. This deficiency may be significantly reduced by using weighted longlines in combination with streamer lines (see Robertson et al. 2006, Dietrich et al. 2008). Streamer lines can also be less efficient under conditions of strong crosswinds that can blow the streamers to the side of the longline, leaving baited
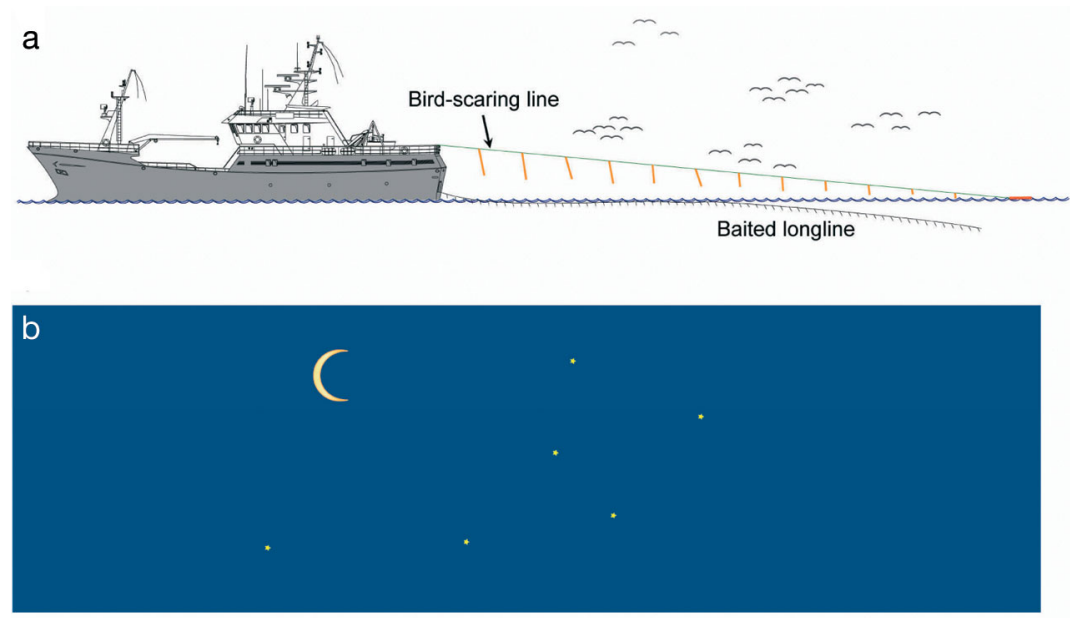

Fig. 1. (a) Streamer lines to scare away birds. Lines were proven to be the most efficient measure to mitigate seabird bycatch in demersal longline fisheries in the northern hemisphere, and in trawl fisheries. (b) Night setting when there is no moonlight was proven to be an efficient mitigation measure in southern hemisphere longline fisheries. Reprinted from Løkkeborg et al. (2010) with permission from John Wiley \& Sons hooks exposed to seabirds (Løkkeborg 1998). Reduced efficiency under crosswind conditions may partly be counteracted by attaching the streamer line to the windward side of the vessel or by using paired streamer lines.

Accordingly, aerial extent and position relative to sinking hooks are the most critical components of streamer line performance. A practical problem with streamer lines is entanglement with the longline gear; the potential for fouling with surface floats and branchlines makes streamer lines more challenging to use in pelagic fisheries (Melvin et al. 2010). A 'light' streamer line (with short streamers) and a 'hybrid' streamer line (with long and short streamers) have been developed for pelagic longlining in order to prevent fouling with the longline gear (see Yokota et al. 2008, Melvin et al. 2010, respectively), but more research is needed to demonstrate the efficiency of these devices.

Night setting. Setting longlines at night has been proven to be a very efficient mitigation method, particularly for albatrosses (Fig. 1b). However, nocturnal foragers (e.g. white-chinned petrel) are also vulnerable to hooks set at night, although at a lower risk. Thus, night setting is more efficient in reducing incidental catch of albatrosses than white-chinned petrel (Table 3). The efficiency of this mitigation measure is lower in bright moonlight and in high latitude fisheries during summer. Longline operations under such conditions and in areas inhabited by nocturnal foragers require additional mitigation measures to effectively reduce seabird captures.

Area and seasonal closure. As seabird mortality rates are generally higher close to breeding colonies during the breeding seasons, seasonal fishing closure is regarded as a fundamental factor in reducing seabird bycatch in CCAMLR fisheries. This measure is applied in some high risk areas such as South Georgia, but not in others such as around the Kerguelen and Crozet Islands, where bycatch of seabirds remains high despite the use of other mitigation measures (CCAMLR 2005a). There is, however, a risk that area or seasonal closures may displace fishing effort leading to increased mortality in other areas.

Weighted lines. All studies testing the effect of weighted lines have shown significant reductions in mortality. However, while weighted lines shorten the zone in which birds may reach baited hooks, they may not entirely eliminate this zone. Line weighting should therefore be used in combination with other mitigation measures (e.g. streamer line, 
Table 3. Seabird bycatch reductions for different mitigation measures tested in demersal and pelagic ${ }^{*}$ longline fisheries

\begin{tabular}{|c|c|c|c|c|}
\hline $\begin{array}{l}\text { Mitigation } \\
\text { measure }\end{array}$ & $\begin{array}{l}\text { Effectiveness } \\
\qquad(\%)\end{array}$ & Seabird species & Area & Source \\
\hline Streamer line & $\begin{array}{c}88-100 \\
71-94 \\
98-100\end{array}$ & $\begin{array}{l}\text { Northern fulmar } \\
\text { Northern fulmar } \\
\text { Northern fulmar }\end{array}$ & $\begin{array}{l}\text { Gulf of Alaska } \\
\text { Bering Sea } \\
\text { Northeast Atlantic }\end{array}$ & $\begin{array}{l}\text { Melvin et al. (2001) } \\
\text { Melvin et al. (2001) } \\
\text { Løkkeborg (2003) }\end{array}$ \\
\hline Night setting & $\begin{array}{c}41 \\
85 \\
81 \\
99 \\
87 \\
100 \\
100 \\
85 \\
79 \\
79\end{array}$ & $\begin{array}{l}\text { White-chinned petrel } \\
\text { White-chinned petrel } \\
\text { White-chinned petrel } \\
\text { Albatrosses } \\
\text { Albatrosses, giant petrel } \\
\text { Albatrosses, giant petrel } \\
\text { Black-browed albatross } \\
\text { Not identified } \\
\text { Not identified } \\
\text { Albatrosses }\end{array}$ & $\begin{array}{l}\text { Indian Ocean } \\
\text { Indian Ocean } \\
\text { Indian Ocean } \\
\text { Indian Ocean } \\
\text { Indian Ocean } \\
\text { South Georgia } \\
\text { Falkland Islands } \\
\text { Australia } \\
\text { Australia } \\
\text { New Zealand }\end{array}$ & $\begin{array}{l}\text { Cherel et al. (1996) }{ }^{\mathrm{a}} \\
\text { Cherel et al. }(1996)^{\mathrm{b}} \\
\text { Weimerskirch et al. (2000) } \\
\text { Weimerskirch et al. (2000) } \\
\text { Nel et al. 2002 } \\
\text { Ashford et al. (1995) } \\
\text { Reid et al. (2004) } \\
\text { Brothers et al. (1999b) }{ }^{*} \\
\text { Klaer \& Polacheck (1998)* } \\
\text { Murray et al. (1993) }{ }^{*}\end{array}$ \\
\hline Weighted lines & $\begin{array}{c}37 \\
76 \\
80 \\
\\
94-99 \\
61 \\
93\end{array}$ & $\begin{array}{l}\text { Northern fulmar } \\
\text { Northern fulmar } \\
\text { Black-browed albatross, } \\
\text { white-chinned petrel } \\
\text { White-chinned petrel } \\
\text { Sooty shearwater } \\
\text { White-chinned petrel, black- } \\
\text { browed and shy albatross }\end{array}$ & $\begin{array}{l}\text { Gulf of Alaska } \\
\text { Bering Sea } \\
\text { South Georgia } \\
\text { New Zealand } \\
\text { New Zealand } \\
\text { South Africa }\end{array}$ & $\begin{array}{l}\text { Melvin et al. (2001) } \\
\text { Melvin et al. (2001) } \\
\text { Agnew et al. (2000) } \\
\text { Robertson et al. (2006) } \\
\text { Robertson et al. (2006) } \\
\text { Melvin et al. (2010) }\end{array}$ \\
\hline Setting funnel & $\begin{array}{c}79 \\
72-92 \\
67 \\
100\end{array}$ & $\begin{array}{l}\text { Northern fulmar } \\
\text { Northern fulmar } \\
\text { White-chinned petrel } \\
\text { Laysan albatross }\end{array}$ & $\begin{array}{l}\text { Bering Sea } \\
\text { Northeast Atlantic } \\
\text { Indian Ocean } \\
\text { Hawaii }\end{array}$ & $\begin{array}{l}\text { Melvin et al. }(2001) \\
\text { Løkkeborg }(1998,2001) \\
\text { Ryan \& Watkins }(2002) \\
\text { Gilman et al. }(2003)^{*}\end{array}$ \\
\hline Line shooter & $\begin{array}{c}+54 \\
59\end{array}$ & $\begin{array}{l}\text { Northern fulmar } \\
\text { Northern fulmar }\end{array}$ & $\begin{array}{l}\text { Bering Sea } \\
\text { Northeast Atlantic }\end{array}$ & $\begin{array}{l}\text { Melvin et al. (2001) } \\
\text { Løkkeborg \& Robertson (2002) }\end{array}$ \\
\hline Bait-casting machine & 50 & Not identified & Australia & Klaer \& Polacheck (1998)* \\
\hline Offal discharge & $\begin{array}{l}98 \\
54\end{array}$ & $\begin{array}{l}\text { White-chinned petrel } \\
\text { White-chinned petrel }\end{array}$ & $\begin{array}{l}\text { Indian Ocean } \\
\text { Indian Ocean }\end{array}$ & $\begin{array}{l}\text { Cherel et al. (1996) } \\
\text { Weimerskirch et al. (2000) }\end{array}$ \\
\hline
\end{tabular}

underwater setting, side setting, night setting) in high risk areas.

Longlines with external weights sink unevenly; with demersal gear, the weights must be tied and removed every time the line is set and hauled, which is a laborious process that may be risky to crew members. These problems have been solved for demersal fisheries by the development of multifilament lines with integrated weight, which are practical in use and have a high level of industry support. However, vessels using the Spanish double line system have to use attached weights.

In pelagic longlining, leaded swivels are used to increase sink rates. However, there is a reluctance to use leaded swivels due to safety concerns as weighted swivels may cause serious injuries when they recoil back at the crew in the event of a line breakage. Attempts to solve this problem by employing 'safe leads', which are designed to slide off the branchline in the event of a breakage, have shown promising results (Sullivan et al. 2010).
Weighted longlines in demersal fisheries may give increased target catch rates as they reach the seabed more rapidly. The release rate of attractants from baits declines rapidly during the first $2 \mathrm{~h}$ of immersion in seawater (Løkkeborg 1990), and longlines with a sink rate of $0.16 \mathrm{~m} \mathrm{~s}^{-1}$ (conventional lines) would take $1 \mathrm{~h} 44 \mathrm{~min}$ to reach a fishing depth of $1000 \mathrm{~m}$ compared to $55 \mathrm{~min}$ for a line weighted to sink at $0.3 \mathrm{~m} \mathrm{~s}^{-1}$ (Robertson et al. 2003). Thus, it is advantageous to use longlines that sink fast to maximise bait attractiveness.

Underwater setting. Studies on underwater setting funnels are few, and the potential of this mitigation measure is not clear. Variations in the depth at which the device delivers the baited hooks and the diving capability of seabird species might explain the inconsistency in the results obtained with this setting method. Thus, the efficiency of this measure is highly dependent on the seabird assemblage and the depth at which baited hooks are exposed. 
There is potential for significant improvements in the performance of this mitigation method, particularly when used in combination with weighted longlines. Work is being carried out in Australia to advance the concept of the underwater setting capsule to the point where this technology becomes practical and costeffective. This work was awarded the 2009 International WWF Smart Gear Competition (see www.smartgear.org/). For an update on the progress in the development of this promising device, see Robertson \& Ashworth (2010).

Strategic offal discharge. The discharge of offal during line setting is a somewhat controversial mitigation measure. Although the dumping of offal has been proven to be very efficient in a study carried out in Kerguelen waters (Cherel et al. 1996), offal discharge is prohibited during longline setting in the CCAMLR Convention Area (CCAMLR Conservation Measure 25-02; CCAMLR 2005b). The use of this method needs to be carefully considered as offal dumping attracts more seabirds to the fishing vessel. Furthermore, the use of offal is not applicable in fisheries such as tuna longlining where line setting lasts for several hours and there is little offal to discharge.

Line shooter, bait-casting machine, thawed bait, blue-dyed bait and olfactory deterrent. Experiments testing these mitigation measures are few and fragmentary. Results showing significant reductions in seabird capture when setting with a line shooter have not been reported, and line shooters did not increase the sink rate of baited hooks (Robertson et al. 2008, 2010b). In fact, Melvin et al. (2001) demonstrated that setting with a line shooter gave increased seabird bycatches, whereas Løkkeborg \& Robertson (2002) obtained decreased (not significant) seabird capture when using a line shooter. The effects of line shooters, line tension and propeller turbulence on the sink rate of baited hooks are poorly understood, and more research is needed to determine how these factors affect seabird mortality.

Investigations testing bait-casting machines have given inconsistent results and these studies have several limitations (see above). Unless bait-casting machines have the capability to allow accurate delivery of baits under the streamer line, baited hooks could be deployed well beyond this area, thus increasing exposure of hooks to seabirds (Robertson 2010b). It has been suggested that the bait thaw status has no practical bearing on seabird mortality in pelagic fisheries because the effect on sink rates is very minor (Robertson 2010a).

Reduced interactions between seabirds and baits dyed blue have only been demonstrated for squid bait, and this method is operationally difficult to use. Dyeing the baits causes extra work for the fishermen, and is not possible in autolining where pieces of bait are cut from whole fish at the moment they are set. Shark liver oil has been proven to be an effective deterrent only for burrow-nesting seabird species (Norden \& Pierre 2007). This mitigation measure also has operational and practical difficulties. More experimental studies would allow a better evaluation of these potential mitigation measures.

\section{STUDIES ON MITIGATION MEASURES IN TRAWL FISHERIES}

Several studies have been conducted to examine interactions between seabirds and trawl fisheries (Table 4). However, most of these studies only describe the problem and identify the cause of mortality, and few studies have tested and determined the effects of mitigation measures on seabird mortality. A detailed review of some of these studies is given by Bull (2009).

In fisheries where trawlers use a netsonde cable, collision with the cable is the major threat to seabirds. Observer data collected on board 4 trawlers (from the former USSR) in the New Zealand squid fishery showed that collision with the netsonde cable accounted for $\sim 90 \%$ of a total of 279 seabird deaths (including 236 white-capped albatrosses Thalassarche steadi and 30 sooty shearwaters) (Bartle 1991). Data from 3 Ukrainian trawlers targeting Patagonian toothfish and mackerel icefish Champsocephalus gunnari on the Kerguelen shelf showed that most of the seabird mortality occurred on one vessel that used a netsonde cable, which caused all albatross deaths (Williams \& Capdeville 1996, Weimerskirch et al. 2000). Whitechinned petrels were observed to have been caught either in the meshes near the headline of the trawl or at the codend. This type of mortality was higher on the trawlers fishing for mackerel icefish (18 birds) than on the toothfish trawlers (one bird). Icefish is smaller than toothfish and is thus easily ingested by birds. Netsonde cables are now banned in New Zealand waters and the CCAMLR area (Bartle 1991, Weimerskirch et al. 2000). However, modern wired net monitoring systems are considered essential to some trawl fisheries (see Melvin et al. 2011).

Interactions with seabirds were shown to be rare in the Australian trawl fishery for toothfish around Macquarie, Heard and MacDonalds Islands, and low mortality rates were ascribed to the current license conditions such as a no-discharge policy and a ban on netsonde cables (Wienecke \& Robertson 2002). Analysis of seabird interactions with this fishery showed that a very low proportion of the seabird observations involved direct contacts with the fishing gear (warps and nets), and most contacts (98\%) were light and did 
not cause any apparent injury. During the 15 cruises analysed, only 18 seabirds were observed to have suffered serious injuries or were likely to have died. Given the large number of bird observations (almost 200000 ), these results show that trawlers are able to operate without causing significant seabird mortalities when proper mitigation measures are used (no dumping of offal and ban on netsonde cables).

Seabird observers on board trawlers operating in waters of the Falkland Islands showed that the vast majority of interactions were contacts between seabirds on the water and the warp cable, which mostly resulted in no apparent injury (Sullivan et al. 2006a). All mortalities recorded were caused by the warp and paravane cables -70 and 3 , respectively (mainly black-browed albatross Thalassarche melanophrys). Seabirds had negligible contacts with the warps when there was no offal discharge, and all deaths occurred at times of offal discharge. Also in the South African hake fishery, mortalities occurred mainly during the dumping of offal, and were more frequent in winter (Watkins et al. 2008). Average mortality rates in winter were 0.09 birds killed $\mathrm{h}^{-1}$ in the absence of dumping compared to 0.56 birds killed $\mathrm{h}^{-1}$ during dumping. In summer, no birds were killed when not dumping compared to 0.21 birds killed $\mathrm{h}^{-1}$ during dumping. Also in the Argentinean trawl fishery for hake, the level of fishing discards and season were the strongest factors explaining the occurrence of seabird interactions (Gonzalez-Zevallos \& Yorio 2006, Favero et al. 2010). These studies suggest that eliminating factory discharge would virtually eliminate seabird mortality.

However, due to space constraints and the volume of waste produced, it is impossible to retain all processing waste on board many trawlers. Therefore, waste management solutions that allow for some discharge while fishing are needed. Abraham et al. (2009) conducted an experiment on whether mincing fish waste before discharge or converting all waste to fishmeal to reduce discharge to sump water reduced the number of seabirds attending a factory trawler in New Zealand waters. Reducing discharge to sump water reduced the number of all groups of seabirds

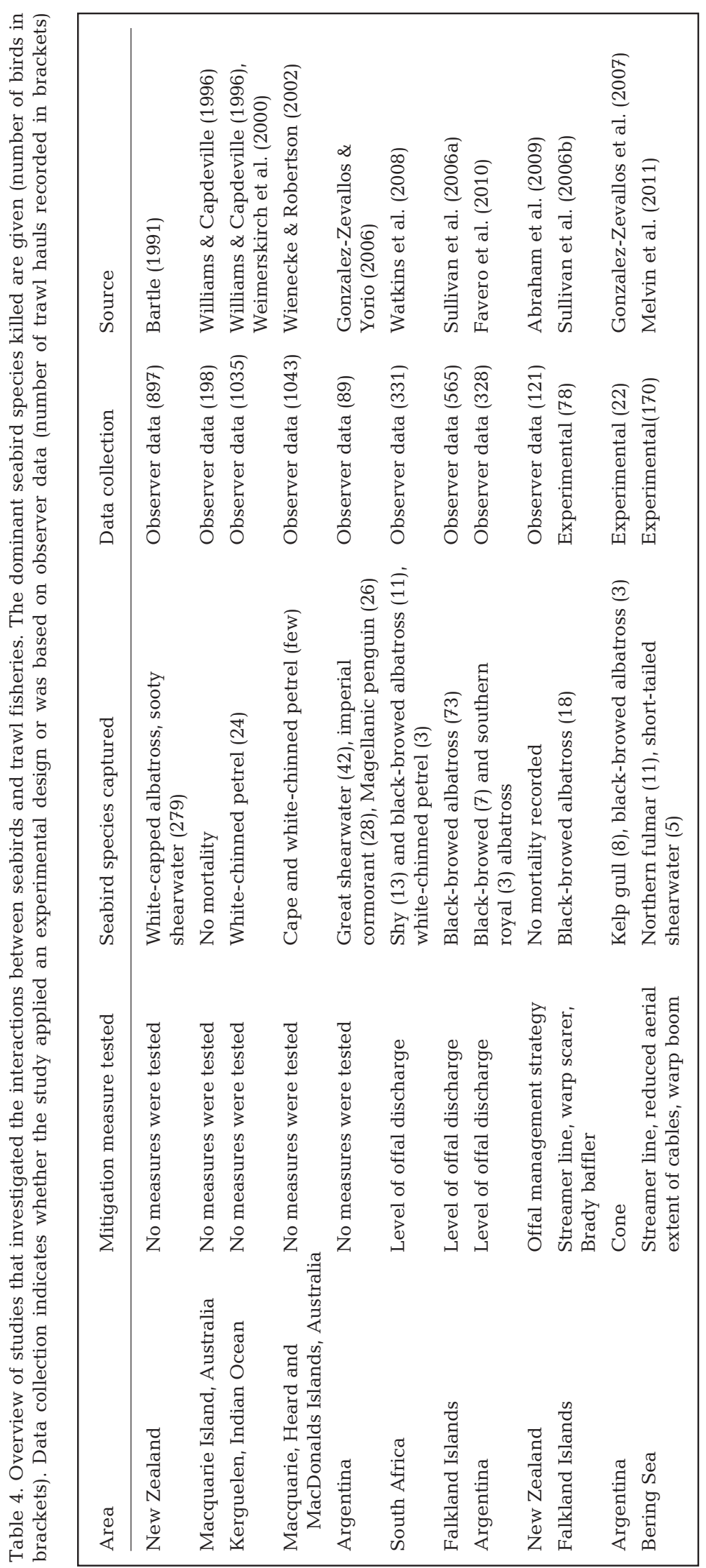


attending the vessel; particularly the abundance of small albatrosses and procellarids was reduced to $<5 \%$ of the number observed when unprocessed discharge was released. Mincing only reduced the numbers of large albatrosses attending the vessel.

Three mitigation measures (paired streamer lines, warp scarer, Brady baffler) were tested under commercial trawling operations in waters of the Falkland Islands (Sullivan et al. 2006b). Mortalities were rare, with $86 \%$ of trawl hauls having no observed mortality. All 3 mitigation measures gave lower seabird mortality than the control with no mitigation device. No seabirds were killed when streamer lines were used, and only one bird was killed with the warp scarer employed compared to 14 birds killed in the control treatment. The rates of seabird contacts with the warp were also reduced with all 3 mitigation devices. Contact rate was significantly lower with streamer lines than with the warp scarer, which in turn resulted in significantly lower contact rate than the Brady baffler. With the significant relationship between seabird mortality and contacts with the warp (Sullivan et al. 2006a), the authors concluded that the contact rate data suggested a performance hierarchy among the 3 mitigation devices. The streamer lines and the warp scarer both performed substantially better than the Brady baffler, while the streamer lines were slightly better than the warp scarer.

Melvin et al. (2011) tested 3 mitigation measures (paired streamer lines, warp boom, snatch block) on board 2 trawlers targeting walleye pollock (Theragra chalcogramma) in the eastern Bering Sea. This study is the only one that also determined interactions with third-wire (netsonde) cables. One of the trawlers rendered offal into fish meal and oil, whereas the other discharged minced offal. Fewer seabirds attended the former trawler, but the rate of seabird cable strikes was higher for this vessel due to the greater aerial extent of its cables. This demonstrates that the aerial extent of the cables has a pronounced effect on seabird interactions. Mortalities were rare (20 birds in 170 trawl hauls) in both trawlers; thus, rates of heavy seabird strikes by netsonde and warp cables using the mitigation measures were compared to a control of no mitigation. Streamer lines significantly reduced seabird strikes with both cable types by over an order of magnitude. The aerial extent of the third wire was reduced by using a snatch block to draw the wire close to the water at the stern; this measure also reduced third-wire strike rates, but it was less effective than streamer lines. The third measure tested, the warp boom, was designed to deter seabirds from the warps, but this method failed to reduce seabird strikes.

The cone (made of plastic and attached to each warp cable) has been tested in the Argentine hake trawl fishery (Gonzalez-Zevallos et al. 2007). In hauls with this device, the number of seabird contacts with the warps was reduced by $89 \%$ compared to control hauls without the device. No seabirds were killed when the mitigation device was used, while 11 birds were killed in control hauls.

\section{STUDIES ON MITIGATION MEASURES IN GILLNET FISHERIES}

Visual and acoustic alerts were tested to reduce seabird bycatch, primarily for the common murre Uria aalge and rhinoceros auklet Cerorhinca monocerata, in the coastal sockeye salmon Onchorhynchus nerka drift net fishery in Puget Sound (Washington, USA) (Melvin et al. 1999). The traditional gillnets (200 meshes, $18.3 \mathrm{~m}$ in depth) made from monofilament nylon and virtually invisible underwater were compared to experimental nets with the upper 20 or 50 meshes being replaced with white multifilament nylon twine, making the upper 1.8 and $4.6 \mathrm{~m}$, respectively, of the nets visible. Nets with 20 visible mesh panels reduced murre bycatch by $45 \%$ and maintained catching efficiency for salmon, whereas auklet bycatch was not reduced. Nets with 50 visible meshes reduced both murre (40\%) and auklet $(42 \%)$ bycatches; however, this modification also reduced the catch rate of salmon by more than half. The acoustic alert tested were pingers attached to the floatline every $50 \mathrm{~m}$. The pingers emitted a $1.5 \mathrm{kHz}$ signal every $4 \mathrm{~s}$ at 35 to $40 \mathrm{~dB}$ above background noise level. Pingers reduced murre bycatch by $50 \%$ and maintained salmon catch rates, but they did not reduce auklet bycatch, i.e. pingers and 20 mesh visible panels gave similar results.

Increasing the sound reflecting properties of gillnets as a method for reducing bycatch of echolocating cetaceans was tested in the demersal fishery in the Bay of Fundy (Canada), and its effect on seabird bycatch was also recorded (Trippel et al. 2003). Traditional monofilament nylon gillnets were compared to nets with strands containing fine barium sulphate particles and dyed pale blue to mask the white opaque colour of the barium sulphate. There was a significant reduction in seabird bycatch (great shearwater Puffinus gravis) in the reflective nets, with 11 seabirds being caught in 72 reflective nets $\left(0.15\right.$ birds net $\left.^{-1}\right)$ compared to 94 seabirds in 121 control nets $\left(0.78\right.$ birds net $\left.{ }^{-1}\right)$. The reduction $(80 \%)$ was explained by the increased visibility of the blue opaque net. There was also a significant reduction in harbour porpoise Phocoena phocoena bycatch in reflective nets, but no reduction in target fish catches (mainly gadoids).

In their study of the drift net fishery in Puget Sound, Melvin et al. (1999) also investigated the effects of fishing time (i.e. dawn, day, dusk), and found that both 
salmon and seabird catches were highest at dawn. Precluding sunrise fishing gave pronounced reductions in both auklet and murre bycatches and only a small reduction $(5 \%)$ in salmon catches.

In the Japanese high-seas drift gillnet fishery for flying squid Ommastrephes bartrami, seabird entanglements were compared between nets submerged $2 \mathrm{~m}$ below the surface and traditional surface nets (Hayase \& Yatsu 1993 cited by Melvin et al. 1999). Seabird bycatch was significantly reduced in submerged nets; however, fishing efficiency was also reduced by up to $95 \%$.

\section{CONCLUSIONS}

There is potential for considerable reductions in seabird mortality rates in all longline fisheries when appropriate and effective mitigation measures are employed. Analyses of observer data over a period of several years have shown pronounced reductions in seabird bycatch rates in many fisheries (Murray et al. 1993, Ashford \& Croxall 1998, Agnew et al. 2000, Gilman et al. 2003, Reid et al. 2004). In the toothfish fishery around South Georgia, for example, the bycatch rate has been reduced from 0.66 birds per 1000 hooks in 1993 to 0.0003 birds per 1000 hooks in 2003 as a result of the implementation of and increase in compliance with the CCAMLR Conservation Measure 25-02 (Reid et al. 2004). In the demersal longline fisheries in Alaska, annual bycatch rates (birds per 1000 hooks) decreased by an average of $80 \%$ from 0.0051 to 0.0127 prior to the implementation of mitigation measures to 0.0015 to 0.0017 after implementation (Cox et al. 2007). Murray et al. (1993) estimated total annual seabird mortality by extrapolating the observer bycatch data to the total effort of the Japanese tuna fleet in New Zealand waters, and found that mortality declined from 3652 birds in 1988 to 360 birds in 1992, probably as a result of the introduction of mitigation measures (streamer lines and night setting). Important prerequisites for successful implementation of effective mitigation measures in commercial fisheries are collaborations between the fishing industry and scientists, monitoring, and compliance via enforcement and incentives (Cox et al. 2007).

There is an economic incentive for longline fishermen to use mitigation measures as loss of baits to scavenging seabirds reduces the catching efficiency of their fishing gear. Longlines set through an underwater setting chute had lower bait loss than longlines set without the chute (10 vs. $31 \%$; Gilman et al. 2003), and streamer lines have also been shown to reduce bait loss caused by seabirds (Løkkeborg 2003). In the latter study, which was carried out in the Norwegian demersal autoline fishery, longlines set with a streamer line gave $32 \%$ higher target catch rates than those set without this measure (Løkkeborg 2001). These results suggest that fishermen would benefit from increased catches if they employ effective mitigation measures.

There is no single solution to the mitigation of incidental seabird mortality in longline fisheries. The current review provides strong evidence that the efficiency of a mitigation measure is specific to each fishery. In particular, the effectiveness of a given mitigation device is influenced by the seabird species assemblage at the fishing ground considered (surface vs. diving foragers, diurnal vs. nocturnal foragers). For example, several studies have shown that night setting is a very efficient mitigation measure for most albatrosses but is not as effective for white-chinned petrel (e.g. Ashford et al. 1995, Weimerskirch et al. 2000, Nel et al. 2002). The type of longline gear is also likely to be an important factor affecting the efficiency of a mitigation measure (demersal vs. pelagic longline, single vs. Spanish-rigged demersal longline).

Some conclusions, however, can be drawn based on the studies conducted to date. In demersal longline fisheries in the northern hemisphere (Atlantic Ocean and Pacific Ocean), where northern fulmar is the dominant seabird captured, streamer lines have been proven to be very efficient. As the Pacific Ocean and the Bering Sea are inhabited by endangered and threatened species such as albatrosses, additional care should be taken by using paired streamer lines and/or weighted longlines in the demersal fisheries carried out in areas inhabited by these species. In the demersal fishery for Patagonian toothfish, night setting in combination with seasonal closure during the breeding season in areas adjacent to seabird colonies has resulted in considerable reductions in albatross mortality.

In pelagic longline fisheries, night setting has been shown to be an important and efficient mitigation measure. Although night setting alone may still reduce bycatch of nocturnal species such as white-chinned petrel, this measure has to be used in combination with other measures when fishing in areas inhabited by nocturnal seabirds and when fishing in bright moonlight. Based on conclusions from a wide range of studies, the combination of streamer lines and weighted branch lines would greatly reduced incidental bycatch of nocturnal and diving seabirds, which are among the most difficult to deter from baited hooks.

Although few studies have been conducted in trawl fisheries, the results reported to date indicate rare interactions between seabirds and trawl gear at times of no offal discharge. These studies therefore suggest that a no-discharge policy would virtually eliminate seabird mortality, and strategic management of offal discharge is probably the most critical mitigation mea- 
sure in trawl fisheries (Gonzalez-Zevallos et al. 2007, Abraham et al. 2009, Favero et al. 2010). Streamer lines were proven to be an effective measure in that no seabirds were killed when streamer lines were used during trawling carried out under factory discharge and in the spring when albatross density peaks (Sullivan et al. 2006b). However, the longline studies demonstrated that seabird interactions are specific to each fishery, and therefore more studies need to be conducted in other areas and trawl fisheries.

Studies in gillnet fisheries are even more scarce, and development of seabird mitigation measures for this gear type is in its infancy. This review has identified only one study where a mitigation method (increased visibility of the net) was proven to be efficient in reducing seabird bycatch while maintaining target species catch rates (Trippel et al. 2003).

\section{FUTURE RESEARCH NEEDS}

Future research on seabird mitigation measures in longlining should apply an experimental approach to fine-tune the most promising mitigation measures for each specific fishery. Research on streamer lines should compare the attack or dive rate of seabird species as a function of the aerial extent of the streamer line in order to optimise designs particularly for pelagic longline fisheries. This work should be carried out in combination with appropriate line weighting regimes in order to reduce the area in which birds have access to baited hooks (see Melvin et al. 2010). Other aspects of streamer lines that need research are performance under crosswind conditions (paired streamer lines, offsetting towed devices) and fouling with the longline gear ('light/hybrid' streamer lines in pelagic fisheries).

More research on the effects of weighted longlines in reducing seabird capture is needed. The concept of integrated weight was designed for multifilament demersal longlines, and alternatives to adding external weights for monofilament and pelagic longlines (e.g. weighted swivels, 'safe leads') should be a research priority (see Robertson et al. 2010a, Sullivan et al. 2010). The line weighting regime, appropriate sink rate and combination of other mitigation measures need to be determined for a specific fishery. Future research should also include the concepts of underwater setting and side setting (see Yokota \& Kiyota 2006 and Gilman et al. 2007 for side setting).

Finally, to solve the global problem of seabird mortality in longline fisheries, broad use of effective mitigation measures in all fisheries that have a problem with seabird bycatch is essential. To achieve this goal, it is important to provide fishermen with incentives for voluntary use of seabird avoidance methods (Gilman et al. 2003). Reduced seabird interactions and increased bait retention should provide the economic incentive of achieving higher target catch. Therefore, data on bait loss and target fish catch rates need to be collected in future experiments in order to demonstrate increased profitability when using seabird mitigation measures. Furthermore, the ideal seabird mitigation method should also be practical and convenient for fishermen to employ, and easy for managers to enforce.

Mitigation measures have been tested in only a few trawl fisheries. Knowledge on best practices to prevent seabird bycatch in these fisheries is therefore fragmentary, and effort needs to be expanded to other areas where interactions with seabirds occur. Future research should be based on the promising results obtained for measures such as strategic offal discharge, streamer lines and reduced areal extent of cables. Work in trawl fisheries should also focus on mortalities due to entanglement in net meshes.

Effective mitigation measures still have to be identified for gillnet fisheries. Development of appropriate measures that maintain catching efficiency for target species is challenging.

\section{LITERATURE CITED}

Abraham ER, Pierre JP, Middelton DAJ, Cleal J, Walker NA, Waugh SM (2009) Effectiveness of fish waste management strategies in reducing seabird attendance at a trawl vessel. Fish Res 95:210-219

Agnew DJ, Black AD, Croxall JP, Parkes GB (2000) Experimental evaluation of the effectiveness of weighting regimes in reducing seabird by-catch in the longline toothfish fishery around South Georgia. CCAMLR Sci 7:119-131

Ashford JR, Croxall JP (1998) An assessment of CCAMLR measures employed to mitigate seabird mortality in longlining operations for Dissosticus eleginoides around South Georgia. CCAMLR Sci 5:217-230

Ashford JR, Croxall JP, Rubilar PS, Moreno CA (1995) Seabird interactions with longlining operations for Dissosticus eleginoides around South Georgia, April to May 1994. CCAMLR Sci 2:111-121

Barnes KN, Ryan PG, Boix-Hinzen C (1997) The impact of the hake Merluccius sp. longline fishery off South Africa on Procellariiform seabirds. Biol Conserv 82:227-234

Bartle JA (1991) Incidental capture of seabirds in the New Zealand subantarctic squid trawl fishery, 1990. Bird Conserv Int 1:351-359

Belda EJ, Sanchez A (2001) Seabird mortality on longline fisheries in the western Mediterranean: factors affecting bycatch and proposed mitigation measures. Biol Conserv 98:357-363

Boggs CH (2001) Deterring albatrosses from contacting baits during swordfish longline sets. In: Melvin EF, Parrish JK (eds) Seabird bycatch: trends, roadblocks, and solutions. University of Alaska Sea Grant, AK-SG-01-01, Fairbanks, p 79-94

Brothers N (1991) Albatross mortality and associated bait loss in Japanese longline fishery in the Southern Ocean. Biol Conserv 55:255-268 
Brothers NP, Cooper J, Løkkeborg S (1999a) The incidental catch of seabirds by longline fisheries: worldwide review and technical guidelines for mitigation. FAO Fisheries Circular No. 937, Rome

$>$ Brothers N, Gales R, Reid T (1999b) The influence of environmental variables and mitigation measures on seabird catch rates in the Japanese tuna longline fishery within the Australian Fishing Zone, 1991-1995. Biol Conserv 88: 85-101

Brown J, Brickle P, Hearne S, French G (2010) An experimental investigation on the 'umbrella' and 'Spanish' system of longline fishing for the Patagonian toothfish (Dissostichus eleginoides) in the Falkland Islands: implications for stock assessment and seabird by-catch. Fish Res 106:404-412

Bugoni L, Mancini PL, Monteiro DS, Nascimento L, Neves TS (2008) Seabird bycatch in the Brazilian pelagic longline fishery and a review of capture rates in the southwestern Atlantic Ocean. Endang Species Res 5:137-147

Bull LS (2007) Reducing seabird bycatch in longline, trawl and gillnet fisheries. Fish Fish 8:31-56

Bull LS (2009) New mitigation measures reducing seabird bycatch in trawl fisheries. Fish Fish 10:408-427

CCAMLR (2005a) Report of the twenty-fourth meeting of the Scientific Committee SC-CAMLR-XXIV. Commission for the Conservation of Atlantic Marine Living Resources, Hobart, Australia

CCAMLR (2005b) Schedule of conservation measures in force, 2005/06. Commission for the Conservation of Atlantic Marine Living Resources, Hobart, Australia

> Cherel Y, Weimerskirch H, Duhamel G (1996) Interaction between longline vessels and seabirds in Kerguelen waters and a method to reduce seabird mortality. Biol Conserv 75:63-70

Cocking LJ, Double MC, Milburn PJ, Brando VE (2008) Seabird bycatch mitigation and blue-dyed bait: a spectral and experimental assessment. Biol Conserv 141: 1354-1364

Cox TM, Lewison RL, Zydelis R, Crowder LB, Safina C, Read AJ (2007) Comparing effectiveness of experimental and implemented bycatch reduction measures: the ideal and the real. Conserv Biol 21:1155-1164

Croxall JP, Rothery P, Pickering S, Prince PA (1990) Reproductive performance, recruitment and survival of wandering albatrosses Diomedea exulans at Bird Island, South Georgia. J Anim Ecol 59:775-796

- Dietrich KS, Melvin EF, Conquest L (2008) Integrated weight longlines with paired streamer lines-Best practice to prevent seabird bycatch in demersal longline fisheries. Biol Conserv 141:1793-1805

Favero M, Blanco G, Garcia G, Copello S and others (2010) Seabird mortality associated with ice trawlers in the Patagonian shelf: effect of discards on the occurrence of interactions with fishing gear. Anim Conserv 14:131-139

Gales R, Brothers N, Reid T (1998) Seabird mortality in the Japanese tuna longline fishery around Australia, 1988-1995. Biol Conserv 86:37-56

Gilman E, Boggs C, Brothers N (2003) Performance assessment of an underwater setting chute to mitigate seabird bycatch in the Hawaii pelagic longline tuna fishery. Ocean Coast Manage 46:985-1010

Gilman E, Brothers N, Kobayashi DR (2005) Principles and approaches to abate seabird by-catch in longline fisheries. Fish Fish 6:35-49

> Gilman E, Brothers N, Kobayashi DR (2007) Comparison of 3 seabird bycatch avoidance methods in Hawaii-based pelagic longline fisheries. Fish Sci 73:208-210

Gislason H (1994) Ecosystem effects of fishing activities in the
North Sea. Mar Pollut Bull 29:520-527

Gómez-Laich A, Favero M (2007) Spatio-temporal variation in mortality rates of white-chinned petrels Procellaria aequinoctialis interacting with longliners in the southwest Atlantic. Bird Conserv Int 17:359-366

Gonzalez-Zevallos D, Yorio P (2006) Seabird use of discards and incidental captures at the Argentine hake trawl fishery in the Golfo San Jorge, Argentina. Mar Ecol Prog Ser 316:175-183

Gonzalez-Zevallos D, Yorio P, Caille G (2007) Seabird mortality at trawler warp cables and a proposed mitigation measure: a case study in Golfo San Jorge, Patagonia, Argentina. Biol Conserv 136:108-116

$>$ Huin N (1994) Diving depths of white-chinned petrels. Condor 96:1111-1113

> Jiménez S, Domingo A, Brazeiro A (2009) Seabird bycatch in the Southwest Atlantic: interaction with the Uruguayan pelagic longline fishery. Polar Biol 32:187-196

Jiménez S, Abreu M, Pons M, Ortiz M, Domingo A (2010) Assessing the impact of the pelagic longline fishery on albatrosses and petrels in the southwest Atlantic. Aquat Living Resour 23:49-64

Klaer N, Polacheck T (1998) The influence of environmental factors and mitigation measures on by-catch rates of seabirds by Japanese longline fishing vessels in the Australian region. Emu 98:305-316

Lewison RL, Nel DC, Taylor F, Croxall JP, Rivera KS (2005) Thinking big - taking a large-scale approach to seabird bycatch. Mar Ornithol 33:1-5

Løkkeborg S (1990) Rate of release of potential feeding attractants from natural and artificial bait. Fish Res 8:253-261

$>$ Løkkeborg S (1998) Seabird by-catch and bait loss in longlining using different setting methods. ICES J Mar Sci 55: 145-149

Løkkeborg S (2001) Reducing seabird bycatch in longline fisheries by means of bird-scaring lines and underwater setting. In: Melvin EF, Parrish JK (eds) Seabird bycatch: trends, roadblocks, and solutions. University of Alaska Sea Grant, AK-SG-01-01, Fairbanks, p 33-41

Løkkeborg S (2003) Review and evaluation of 3 mitigation measures - bird-scaring line, underwater setting and line shooter - to reduce seabird bycatch in the north Atlantic longline fishery. Fish Res 60:11-16

Løkkeborg S, Bjordal A (1992) Reduced bait loss and bycatch of seabirds in longlining by using a seabird scarer. Document to Working Group FSA-92 CCAMLR, Hobart, Australia, $5 \mathrm{p}$

> Løkkeborg S, Robertson G (2002) Seabird and longline interactions: effects of a bird-scaring streamer line and line shooter on the incidental capture of northern fulmars Fulmarus glacialis. Biol Conserv 106:359-364

Løkkeborg S, Fernö A, Humborstad OB (2010) Fish behavior in relation to longlines. In: He P (ed) Behavior of marine fishes: capture process and conservation challenges. Wiley-Blackwell, Iowa State Univ Press, Ames, IA, p 105-141

Melvin EF, Parrish JK, Conquest LL (1999) Novel tools to reduce seabird bycatch in coastal gillnet fisheries. Conserv Biol 13:1386-1397

Melvin EF, Parrish JK, Dietrich KS, Hamel OS (2001) Solutions to seabird bycatch in Alaska's demersal longline fisheries. Washington Sea Grant Program Project A/FP-7 WSG-AS 01-01

Melvin EF, Sullivan B, Robertson G, Wienecke B (2004) A review of the effectiveness of streamer lines as a seabird by-catch mitigation technique in longline fisheries and CCAMLR streamer line requirements. CCAMLR Sci 11: 189-201 
Melvin EF, Guy TJ, Read LB (2010) Shrink and defend: a comparison of 2 streamer line designs in the 2009 South Africa tuna fishery. Report to the Third Meeting of the Seabird Bycatch Working Group, Agreement on the Conservation of Albatrosses and Petrels, SBWG-3 Doc 13, Mar del Plata, Argentina

Melvin EF, Dietrich KS, Fitzgerald S, Cardoso T (2011) Reducing seabird strikes with trawl cables in the pollock catcher-processor fleet in the eastern Bering Sea. Polar Biol 34:215-226

Moloney CL, Cooper J, Ryan PG, Siegfried WR (1994) Use of a population model to assess the impact of longline fishing on wandering albatrosses Diomedea exulans populations. Biol Conserv 70:195-203

Moreno CA, Rubilar PS, Marschoff E, Benzaquen L (1996) Factors affecting the incidental mortality of seabirds in the Dissostichus eleginoides fishery in the southwest Atlantic (Subarea 483, 1995 season). CCAMLR Sci 3:79-91

Moreno CA, Castro R, Mújica LJ, Reyes P (2008) Significant conservation benefits obtained from the use of a new fishing gear in the Chilean Patagonian toothfish fishery. CCAMLR Sci 15:79-91

Murray TE, Bartel JA, Kalish R, Taylor PR (1993) Incidental capture of seabirds by Japanese bluefin tuna longline vessels in New Zealand waters, 1988-1992. Biol Conserv 3:181-210

Nel DE, Ryan PG, Watkins BP (2002) Seabird mortality in the Patagonian toothfish longline fishery around the Prince Edward Islands, 1996-2000. Antarct Sci 14:151-161

Norden WS, Pierre JP (2007) Exploiting sensory ecology to reduce seabird by-catch. Emu 107:38-43

> O'Toole D, Molloy J (2000) Preliminary performance assessment of an underwater line setting device for pelagic longline fishing. N Z J Mar Freshw Res 34:455-461

Petersen SL, Honig MB, Ryan PG, Underhill LG (2009) Seabird bycatch in the pelagic longline fishery off southern Africa. Afr J Mar Sci 31:191-204

Pierre JP, Norden WS (2006) Reducing seabird bycatch in longline fisheries using a natural olfactory deterrent. Biol Conserv 130:406-415

> Poncet S, Robertson G, Phillips RA, Lawton K, Phalan B, Trathan PN, Croxall JP (2006) Status and distribution of wandering, black-browed and grey-headed albatrosses breeding at South Georgia. Polar Biol 29:772-781

Prince PA, Rothery P, Croxall JP, Wood AG (1994) Population dynamics of black-browed and grey-headed albatrosses Diomedea melanophrys and D. chrysostoma at Bird Island, South Georgia. Ibis 136:50-71

Prince PA, Croxall JP, Trathan PN, Wood AG (1998) The pelagic distribution of South Georgia albatrosses and their relationship with fisheries. In: Robertson G, Gales R (eds) Albatross biology and conservation. Surrey Beatty \& Sons, Chipping Norton, p137-167

Reid TA, Sullivan BJ, Pompert J, Enticott JW, Black AD (2004) Seabird mortality associated with Patagonian toothfish (Dissostichus eleginoides) longliners in Falkland Islands waters. Emu 104:317-325

Robertson G (2001) Effect of line sink rate on albatross mortality in the Patagonian toothfish longline fishery. In: Melvin EF, Parrish JK (eds) Seabird bycatch: trends, roadblocks, and solutions. University of Alaska Sea Grant, AK-SG-0101, Fairbanks, p 43-60

Robertson G (2010a) Static water sink rate trials to improve understanding of sink rates estimates at sea. Report to the Third Meeting of the Seabird Bycatch Working Group, Agreement on the Conservation of Albatrosses and Petrels, SBWG-3 Doc 31, Mar del Plata, Argentina
Robertson G (2010b) Concern about the potential for bait casting machines to increase seabird mortality in the high seas Japanese-style tuna fishery. Report to the Third Meeting of the Seabird Bycatch Working Group, Agreement on the Conservation of Albatrosses and Petrels, SBWG-3 Doc 4, Mar del Plata, Argentina

Robertson G, Ashworth P (2010) Progress on the development and testing of the underwater bait setter for pelagic longline fisheries. Report to the Third Meeting of the Seabird Bycatch Working Group, Agreement on the Conservation of Albatrosses and Petrels, SBWG-3 Doc 6, Mar del Plata, Argentina

Robertson G, Moe E, Haugen R, Wienecke B (2003) How fast do demersal longlines sink? Fish Res 62:385-388

Robertson G, McNeill M, Smith N, Wienecke B, Candy S, Olivier F (2006) Fast sinking (integrated weight) longlines reduce the mortality of white-chinned petrels (Procellaria aequinoctialis) and sooty shearwaters (Puffinus griseus) in demersal longline fisheries. Biol Conserv 132:458-471

> Robertson G, Moreno CA, Crujeiras J, Wienecke B, Gandini P, McPherson G, Seco Pon JP (2007) An experimental assessment of factors affecting the sink rates of Spanishrig longlines to minimize impacts on seabirds. Aquat Conserv 17:S102-S121

Robertson G, Williamson J, McNeill M, Candy SG, Smith N (2008) Autoliners and seabird by-catch: do line setters increase the sink rate of integrated weight longlines? CCAMLR Sci 15:107-114

> Robertson G, Candy SG, Wienecke B, Lawton K (2010a) Experimental determinations of factors affecting the sink rates of baited hooks to minimize seabird mortality in pelagic longline fisheries. Aquat Conserv 20:632-643

Robertson G, Candy SG, Wienecke B (2010b) Effect of line shooter and mainline tension on the sink rates of pelagic longlines and implications for seabird interactions. Aquat Conserv 20:419-427

- Ryan PG, Watkins BP (2002) Reducing incidental mortality of seabirds with an underwater longline setting funnel. Biol Conserv 104:127-131

Sanchez A, Belda EJ (2003) Bait loss caused by seabirds in longline fisheries in the northwestern Mediterranean: is night setting an effective mitigation measure? Fish Res 60: 99-106

Sullivan BJ, Reid TA, Bugoni L (2006a) Seabird mortality on factory trawlers in the Falkland Islands and beyond. Biol Conserv 131:495-504

Sullivan BJ, Brickle P, Reid TA, Bone DG, Middleton DAJ (2006b) Mitigation of seabird mortality on factory trawlers: trials of 3 devices to reduce warp cable strikes. Polar Biol 29:745-753

Sullivan B, Kibel P, Robertson G, Kibel B, Goren M, Wienecke B, Candy S (2010) Safe lead for safe heads: safer line weights for pelagic longline fisheries. Report to the Third Meeting of the Seabird Bycatch Working Group, Agreement on the Conservation of Albatrosses and Petrels, SBWG-3 Doc 16, Mar del Plata, Argentina

> Trippel E, Holy NL, Palka DL, Shepherd TD, Melvin GD, Terhune JM (2003) Nylon barium sulphate gillnet reduces porpoise and seabird mortality. Mar Mamm Sci 19: 240-243

Watkins BP, Petersen SL, Ryan PG (2008) Interactions between seabirds and deep-water hake trawl gear: an assessment of impacts in South African waters. Anim Conserv 11:247-254

> Weimerskirch H, Jouventin P (1987) Population dynamics of the wandering albatross, Diomedea exulans, of the Crozet Islands: causes and consequences of the population decline. Oikos 49:315-322 
Weimerskirch H, Sagar PM (1996) Diving depths of sooty shearwaters Puffinus griseus. Ibis 138:786-788

Weimerskirch H, Brothers NP, Jouventin P (1997) Population dynamics of wandering albatross Diomedea exulans and the Amsterdam albatross D. amsterdamensis in the Indian Ocean and their relationship with longline fisheries: conservation implications. Biol Conserv 79:257-270

Weimerskirch H, Capdeville D, Duhamel G (2000) Factors affecting the number and mortality of seabirds attending trawlers and long-liners in the Kerguelen area. Polar Biol 23:236-249

Wienecke B, Robertson G (2002) Seabird and seal — fisheries interactions in the Australian Patagonian toothfish Dissostichus eleginoides trawl fishery. Fish Res 54:253-265

Williams R, Capdeville D (1996) Seabird interactions with trawl and longline fisheries for Dissostichus eleginoi-

Editorial responsibility: Yves Cherel,

Villiers-en-Bois, France des and Champsocephalus gunnari. CCAMLR Sci 3: 93-99

Yokota K, Kiyota M (2006) Preliminary report of side-setting experiments in a large sized longline vessel. Report to the Scientific Committee Second Regular Session, Western and Central Pacific Fisheries Commission, WCPFC-SC22006/EB WP-15, Manila, Philippines

Yokota K, Minami H, Kiyota M (2008) Direct comparison of seabird avoidance effect between 2 types of tori-lines in experimental longline operations. Report to the Scientific Committee Fourth Regular Session, Western and Central Pacific Fisheries Commission, WCPFC-SC4-2008/EB-WP7, Port Moresby, Papua New Guinea

Zydelis R, Bellebaum J, Österblom H, Vetemaa M and others (2009) Bycatch in gillnet fisheries - An overlooked threat to waterbird populations. Biol Conserv 142:1269-1281

Submitted: October 13, 2010; Accepted: May 25, 2011 Proofs received from author(s): August 10, 2011 